\title{
Application of Polyammonium Cations to Enzyme-immobilized Electrode: Application as Enzyme Stabilizer for Bilirubin Oxidase
}

\author{
Hajime Katano, ${ }^{* \dagger}$ Hirosuke Tatsumi, $* *$ Takao HibI,* Tokuji Ikeda,* and Toshihide Tsukatani*** \\ *Department of Bioscience, Fukui Prefectural University, Eiheiji-cho, Fukui 910-1195, Japan \\ **International Young Researchers Empowerment Center, Shinshu University, Matsumoto 390-8621, Japan \\ ***Research and Development Division, Nicca Chemical, Co. Ltd., Bunkyo, Fukui 910-8670, Japan
}

\begin{abstract}
Bilirubin oxidase was stored in the solutions containing polyammonium salts for a given time at $30^{\circ} \mathrm{C}$, and the activity was assayed. The enzyme catalyzes the reaction: $4\left[\mathrm{Fe}(\mathrm{CN})_{6}\right]^{4-}+4 \mathrm{H}^{+}+\mathrm{O}_{2} \rightarrow 4\left[\mathrm{Fe}(\mathrm{CN})_{6}\right]^{3-}+2 \mathrm{H}_{2} \mathrm{O}$, and the activity can be measured by the absorbance at the wavelength for the absorption maxima of $\left[\mathrm{Fe}(\mathrm{CN})_{6}\right]^{3-}$. The results show that polyammonium cations comprising quaternary ammonium in the main chain and hydrophilic groups, such as hydroxyl and amide groups, stabilize the enzyme in solution. These polyammonium cations may act like a protective colloid. The membrane-covered electrode containing the polyammonium cations, the enzyme, and $\left[\mathrm{Fe}(\mathrm{CN})_{6}\right]^{4 / 3-}$ in the internal solution phase was constructed. The electrode gave a well-defined current-potential curve with a steady state limiting current due to the polycation- $\left[\mathrm{Fe}(\mathrm{CN})_{6}\right]^{4-13-}$ complex-mediated bioelectrocatalytic current for the reduction of $\mathrm{O}_{2}$. The time-dependent decrease of the limiting current indicates again the stabilizing effect of the polyammonium cations on the enzyme.
\end{abstract}

(Received June 20, 2008; Accepted August 21, 2008; Published November 10, 2008)

\section{Introduction}

In a previous paper, ${ }^{1}$ the voltammetric behavior of complexes of polyammonium cations with anionic redox species, such as hexacyanoferrate, is described. By cyclic voltammetry, the polycation complex species give well-developed anodic and cathodic peak currents. The midpoint potential is variable by the choice of the polyammonium cation. The polycation complex species can be easily localized in the internal solution phase of a dialysis membrane-covered electrode. Thus, the polycation complex species can be applied as an electrontransfer mediator of the catalytic electrode with a redox enzyme.

When the $\mathrm{pH}$ in the solution is higher than the isoelectric point of the enzyme $(\mathrm{pI}<\mathrm{pH})$, the enzyme has negative net charge. It has been known that polyammonium cations associate with negative charged solutes or dispersolids to flocculate or disperse them..$^{2-5}$ In this study, the effect of the polyammonium cations on the stability of BOD in aqueous solution was investigated. We selected bilirubin oxidase (BOD; EC 1.3.3.5) as the redox enzyme, which has been a promising enzyme as a cathode catalyst in biofuel cells. ${ }^{6-8}$ The $\mathrm{pI}$ and the optimum $\mathrm{pH}$ are 4.1 and 6.0, respectively, according to a catalogue from the supplier. We selected polyammonium salts comprising quaternary ammonium in the main chain: poly[(dimethylimino)-1,6hexanediyl](QM1), poly[(dimethylimino)(2-oxo-1,2-ethanediyl)imino-1,6-hexanediylimino(1-oxo-1,2-ethanediyl)(dimethylimino)1,6-hexanediyl] (QM2), quaternized poly[bis(2chloroethyl)ether-alt-1,3-bis[3-(dimethylimino)propyl]urea] (QM3), poly[(dimethylimino)(2-oxo-1,2-ethanediyl)imino-1,2-

$\dagger$ To whom correspondence should be addressed.

E-mail: hajime@fpu.ac.jp ethanediylimino(1-oxo-1,2-ethanediyl)(dimethylimino)-1,3propanediyl] (QM4), poly(dimethylamine-co-epichrohydrin) (QM5) and those in sub chain: poly(diallydimethylammonium) (QS1) and poly[metacrylpropyltrimethylammonium] (QS2). Polyammoniums comprising primary ammonium were also tested with polyamines: poly[allyamine] (PAA), poly[ethyleneimine] (PEI), and poly[lysine] (PLys).

The enzymatic activity of BOD stored in the solution containing the polyammonium salts and buffer components $\mathrm{pH}$ 7.0) for a given time was assayed by a spectrophotometric method. ${ }^{9}$ The results show that some polyammonium cations can stabilize BOD remarkably. A membrane-covered electrode with an internal solution containing BOD and polyammonium was prepared, and was immersed continually into the solution containing $\left[\mathrm{Fe}(\mathrm{CN})_{6}\right]^{4-}$. The cyclic voltammograms $(\mathrm{CVs})$ of the air-saturated solution with the electrode exhibited an Sshaped pattern with a steady state limiting current, which can be assigned to the bioelectrocatalytic current of the reduction of $\mathrm{O}_{2}$-mediated by polyammonium- $\left[\mathrm{Fe}(\mathrm{CN})_{6}\right]^{4-13-}$ complex species. The limiting current was remarkably observed over 1 week, indicating that the polyammonium cations can be applied to the enzyme-immobilized electrode not only as the component of electron-transfer mediator, but also as the stabilizer for enzyme.

\section{Experimental}

\section{Reagents and chemicals}

The BOD from Myrothecium verrucaria was donated from Amano Enzyme Inc. (2.83 U/mg, Lot No. BOBO551301), which was stored at $-80^{\circ} \mathrm{C}$. The BOD was dissolved in the buffered solution at $\mathrm{pH} 7.0$ to prepare a $20 \mathrm{~g} / \mathrm{l}$ BOD standard solution. 
The polyammonium salts of QM1, QM2, and QM4 with $\mathrm{Cl}^{-}$ anion were prepared according to a reported method. ${ }^{10}$ The average molecular weights, $M_{\mathrm{W}}$, of the QM1, QM2, and QM4 salts were 33000,24000 , and 60000 , respectively. The polyammonium salt of QS2 obtained as $17.5 \mathrm{wt} \%$ poly[metacrylpropyltrimethylammonium methylsulfate] $\left(M_{\mathrm{W}}=100000\right)$ aqueous solution form Nicca Chemical Co. Ltd. Polyammonium salts of QM3, QM5, and QS1 with $\mathrm{Cl}^{-}$anion were purchased as a $62 \mathrm{wt} \%$ poly[bis(2-chloroethyl)ether-alt-1,3-bis[3-(dimethylamino)propyl]urea] quaternized solution, a $50 \mathrm{wt} \%$ poly(dimethylamine-co-epichrohydrin) solution, and a $20 \mathrm{wt} \%$ poly(diallydimethylammonium) $\left(M_{\mathrm{W}}=100000\right)$ solution, respectively, from Aldrich. Polyallylamine hydrochloride $\left(M_{\mathrm{W}}\right.$ $=15000$, Aldrich $)$, poly[ethyleneimine $\left(M_{\mathrm{W}}=10000\right.$, Wako $)$, and poly[lysine] $)\left(M_{\mathrm{W}}=15000-30000\right.$, Sigma $)$ were added to the stock solution where the polyamine and polypeptide were charged positively by the protonation. These were used to prepare a $10 \mathrm{~g} / \mathrm{l}$ polyammonium standard solution.

A $0.2 \mathrm{~g} / \mathrm{l}$ BOD stock solution $(\mathrm{pH} 7.0)$ was prepared by mixing the BOD and polyammonium standard solutions and buffer components. The stock solution was stored at $30^{\circ} \mathrm{C}$. 3Morpholinopropanesulfonic acid (MOPS) and bis(2-hydroxyethyl)iminotris(hydroxylmethyl)methane (BisTris) were obtained from Dojindo Laboratories, and used as the buffer components. A solution containing $1 \mathrm{mM} \mathrm{K}_{4}\left[\mathrm{Fe}(\mathrm{CN})_{6}\right]$ and 0.1 $\mathrm{M}$ buffer components ( $\mathrm{pH}$ 7.0) was used as the test solution for the spectrophotometric assay. The test solution was freshly prepared every day with potassium hexacyanoferrate(II) trihydrate (Wako). Other chemicals were reagent-grade materials, and were used without further purification.

\section{Spectrophotometric measurement}

The enzymatic activity was measured as follows. A 2-ml aliquot of the test solution was poured into a spectrophotometer cuvette ( $1 \mathrm{~cm}$ light path). A $20-\mu \mathrm{l}$ aliquot of the BOD stock solution was added to the test solution. Immediately after addition of the BOD stock solution, the cuvette was shaken for $10 \mathrm{~s}$, and was then set in a UV-visible spectrophotometer (JASCO V-530). The absorbance-time curve was recorded, as shown in Fig. 1 below.

\section{Electrochemical measurements}

A dialysis membrane-covered electrode was prepared as follows. A 10- $\mu \mathrm{l}$ aliquot of $0.4 \mathrm{~g} / \mathrm{l} \mathrm{BOD}, 2 \mathrm{~g} / \mathrm{l}$ QM4 salt solution was dropped onto the surface of a PFC electrode (BAS 002409). After the solvent was allowed to evaporate, the electrode surface was covered with a dialysis membrane (Viskase Inc., cut-off molecular weight of $3500,20-\mu \mathrm{m}$ thick in the dry state). The whole electrode was covered by nylon net to give it physical strength.

Voltammetric experiment was performed using a threeelectrode system. The membrane-covered electrode, a platinum coil, and an $\mathrm{Ag} \mid \mathrm{AgCl}(0.1 \mathrm{M} \mathrm{KCl})$ electrode were used as the working electrode, the counter electrode, and the reference electrode, respectively. The CVs were recorded with a homemade electrochemical analyzer.

\section{Results and Discussion}

In the presence of oxygen in solution, BOD catalyzes the following reaction:

$$
4\left[\mathrm{Fe}(\mathrm{CN})_{6}\right]^{4-}+4 \mathrm{H}^{+}+\mathrm{O}_{2} \longrightarrow 4\left[\mathrm{Fe}(\mathrm{CN})_{6}\right]^{3-}+2 \mathrm{H}_{2} \mathrm{O} \text {. }
$$

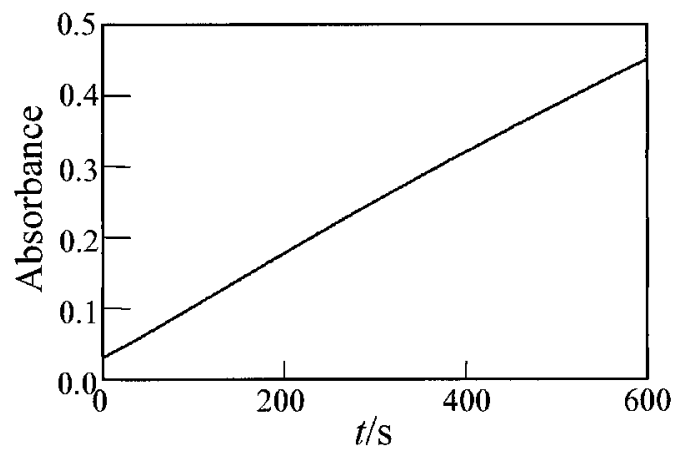

Fig. 1 Absorbance at $420 \mathrm{~nm} v$ s. time curve for $1 \mathrm{mM} \mathrm{K}_{4}\left[\mathrm{Fe}(\mathrm{CN})_{6}\right]$, $0.1 \mathrm{M}$ MOPS-NaOH test solution ( $\mathrm{pH} 7.0$ ) after adding the $0.2 \mathrm{~g} / \mathrm{l}$ BOD, 0.1 M MOPS-NaOH stock solution ( $\mathrm{pH}$ 7.0) immediately after preparation.

The $1 \mathrm{mM} \mathrm{K}_{3}\left[\mathrm{Fe}(\mathrm{CN})_{6}\right]$ aqueous solution was yellow, and the absorption maxima was observed at $420 \mathrm{~nm}$. On the other hand, the $1 \mathrm{mM} \mathrm{K}_{4}\left[\mathrm{Fe}(\mathrm{CN})_{6}\right]$ solution was colorless. Therefore, the activity of BOD can be assayed by measuring the timedependence of the absorbance at $420 \mathrm{~nm}$ in $1 \mathrm{mM} \mathrm{K}_{4}\left[\mathrm{Fe}(\mathrm{CN})_{6}\right]$ test solution after adding the BOD stock solution. Figure 1 shows the absorbance $v s$. time $(A-t)$ curve obtained for the 0.2 $\mathrm{g} / \mathrm{l}$ BOD, 0.1 M MOPS-NaOH stock solution ( $\mathrm{pH}$ 7.0) immediately after preparation, that is, $A-t$ curve for the BOD stored in $0.1 \mathrm{M}$ MOPS-NaOH (pH 7.0) for 0 day. When $t<300$ $\mathrm{s}$, the absorbance increased linearly with time. In the following, the initial slope of the $A-t$ curve in the range of $t$ from 10 to 110 $\mathrm{s}$ was determined, and the average value $(n=3)$ was used to calculate the relative activity. In this study, the relative activity was referred to the initial slope of $A-t$ curve of each BOD stock solution for 0 day. The BOD stored in $0.1 \mathrm{M}$ MOPS-NaOH at $30^{\circ} \mathrm{C}$ for 1 and 2 days was assayed, and the relative activity was determined to be $0.53 \pm 0.01$ and $0.19 \pm 0.02$, respectively. The half life of $\mathrm{BOD}$ at $30^{\circ} \mathrm{C}$ ( $\mathrm{ca}$. 1 day) is much shorter than that (ca. 20 days) expected from the result of the kinetic study at 50 $-70^{\circ} \mathrm{C},{ }^{9}$ suggesting that the inactivation mechanism may differ in temperature.

In the following, the relative activity of $0.2 \mathrm{~g} / \mathrm{l}$ BOD stored for 2 days in the stock solution containing the polyammonium salts and $0.1 \mathrm{M}$ buffer components $(\mathrm{pH} 7.0)$ at $30^{\circ} \mathrm{C}$ is discussed. The initial slope obtained for the stock solutions for 0 day was in harmony with each other and with that for the solution containing only buffer components, indicating that BOD is not activated by the addition of polyammonium salts and that the spectrophotometric assay is not affected by the formation of the polycation complex with $\left[\mathrm{Fe}(\mathrm{CN})_{6}\right]^{4-13-}$. Therefore, the difference in the relative activity of BOD stored for 2 days would reflect the stability effect of the polyammonium cations on BOD in the stock solutions.

The $0.2 \mathrm{~g} / 1$ BOD stored in the $0.5 \mathrm{~g} / 1$ polyammonium, $0.1 \mathrm{M}$ MOPS-NaOH solution where the molar concentration of the polyammonium salt (e.g. $0.5 \mathrm{~g} / \mathrm{l} \div 33000=15 \mu \mathrm{M}$ for QM1 salt) is higher than that of $\mathrm{BOD}(0.2 \mathrm{~g} / \mathrm{l} \div 68000 \approx 3 \mu \mathrm{M})$ was assayed, and the relative activity values are listed in Table 1. The relative activities of BOD stored in the $0.5 \mathrm{~g} / \mathrm{l} \mathrm{QM} 1, \mathrm{QM} 2$, QS1, and QS2 salts, 0.1 M MOPS- $\mathrm{NaOH}$ solution are as same as that in the solution containing only buffer components, that is, reference value. However, the values obtained in the $0.5 \mathrm{~g} / \mathrm{l}$ QM3, QM4, and QM5 salts, 0.1 M MOPS-NaOH solution are somewhat higher than the reference value. The relative activities of BOD stored in $2 \mathrm{~g} / \mathrm{l}$ polyammonium, 0.1 M MOPS-NaOH are 
Table 1 Relative activities of $0.2 \mathrm{~g} / \mathrm{l}$ BOD stored in 0.5 or $2 \mathrm{~g} / 1$ polyammonium salts or polyamines, $0.1 \mathrm{M}$ MOPS-NaOH solution $(\mathrm{pH} 7.0)$ at $30^{\circ} \mathrm{C}$ for 2 days

\begin{tabular}{|c|c|c|c|c|c|c|c|c|c|c|}
\hline Conc./g l ${ }^{-1}$ & QM1 & QM2 & QM3 & QM4 & QM5 & QS1 & QS2 & PAA & PEI & PLy \\
\hline 0.5 & $0.22 \pm 0.02$ & $0.22 \pm 0.04$ & $0.30 \pm 0.04$ & $0.43 \pm 0.02$ & $0.38 \pm 0.03$ & $0.23 \pm 0.07$ & $0.26 \pm 0.04$ & $0.28 \pm 0.04$ & $0.09 \pm 0.06$ & $0.31 \pm 0.08$ \\
\hline 2 & $0.10 \pm 0.06$ & $0.39 \pm 0.04$ & $0.55 \pm 0.10$ & $0.57 \pm 0.07$ & $0.69 \pm 0.10$ & $0.26 \pm 0.07$ & $0.37 \pm 0.07$ & $0.31 \pm 0.08$ & $0.23 \pm 0.11$ & $0.60 \pm 0.08$ \\
\hline
\end{tabular}

listed also in Table 1. The values for the $2 \mathrm{~g} / \mathrm{l}$ QM3, QM4, and QM5 salts, 0.1 M MOPS-NaOH stock solution were $0.55 \pm$ $0.10,0.57 \pm 0.07$, and $0.69 \pm 0.10$, respectively. These values are remarkably higher than the reference value, indicating clearly the stabilizing effect of the QM3, QM4, and QM5 cations. These polyammonium cations have amide or hydroxyl groups, which are hydrophilic functional groups. They coat on the BOD macromolecule, and may act like a protective colloid to increase the hydrophilicity and to prevent aggregation of the enzyme. The BOD was stored also in the $10 \mathrm{~g} / \mathrm{l} \mathrm{QM} 3, \mathrm{QM} 4$, and QM5 salts, 0.1 M MOPS-NaOH solution. The test solution prepared with the BOD stock solution was emulsified. This may be due to the formation of a large-size cluster of the polyammonium- $\left[\mathrm{Fe}(\mathrm{CN})_{6}\right]^{4-13-}$ complex species. ${ }^{1}$ Although the reproducibility of the spectrophotometric measurement was poor for the emulsion, the slope of the $A-t$ curve was higher than that obtained when BOD was stored in the $2 \mathrm{~g} / \mathrm{l}$ polyammonium, $0.1 \mathrm{M}$ MOPS-NaOH solutions.

For a comparison, BOD stored in the 0.5 and $2 \mathrm{~g} / 1$ polyamines, $0.1 \mathrm{M}$ MOPS-NaOH solution for 2 days was assayed. The relative activities are listed also in Table 1. The value of $0.60 \pm$ 0.08 obtained for the $2 \mathrm{~g} / \mathrm{l}$ PLys stock solution is higher than those for the PAA and PEI, indicating again that hydrophilic amide group plays an important role for the stabilizing of BOD. Also, the value obtained for the $2 \mathrm{~g} / \mathrm{l}$ PLys was as high as those for QM3, QM4, and QM5 salts. However, since the charge number of PLys depends on $\mathrm{pH}$, the polyammonium cations comprising quaternary ammonium are more advantageous in practical use than PLys.

Now since no quaternary ammonium salt corresponding to the monomer unit of the polyammonium salts tested is available, it is not easy to investigate the polymer-effect on the stabilization of BOD. However, polyammonium salts comprising quaternary ammonium are sometimes used as alternatives of quaternary ammonium-type cationic surfactants. Thus, for a comparison, the relative activities of BOD stored in the $0.5 \mathrm{~g} / \mathrm{l}$ trimethylhexadecylammonium chloride, benzyldimethyltetradecylammonium chloride, and cetylpyridinium chloride, $0.1 \mathrm{M}$ MOPS- $\mathrm{NaOH}$ solution at $30^{\circ} \mathrm{C}$ for 2 days were assayed, and were determined to be $\sim 0, \sim 0$, and $0.10 \pm 0.07$, respectively, indicating that the cationic surfactants facilitated the inactivation of BOD. The inactivation may be attributed to denaturation by the hydrophobic effect, which has been known in the case of an anionic surfactant like dodecylsulfate. ${ }^{11}$

In a previous paper, ${ }^{1}$ it has been shown that, in the $\mathrm{NaH}_{2} \mathrm{PO}_{4^{-}}$ $\mathrm{Na}_{2} \mathrm{HPO}_{4}$ buffer system, the divalent $\mathrm{HPO}_{4}{ }^{2-}$ anion affects the formation equilibrium of the polycation complex with the $\left[\mathrm{Fe}(\mathrm{CN})_{6}\right]^{4-13-}$ anion. The $0.2 \mathrm{~g} / \mathrm{l}$ BOD stored in $0.5 \mathrm{~g} / 1 \mathrm{QM} 3$, QM4, and QM5 salts, $0.1 \mathrm{M} \mathrm{NaH} 2 \mathrm{PO}_{4}-\mathrm{Na}_{2} \mathrm{HPO}_{4}$ and BisTris$\mathrm{HCl}$ was assayed. The relative activities are listed in Table 2. In $\mathrm{NaH}_{2} \mathrm{PO}_{4}-\mathrm{Na}_{2} \mathrm{HPO}_{4}$, that is, the $\mathrm{H}_{2} \mathrm{PO}_{4}{ }^{-}-\mathrm{HPO}_{4}{ }^{2-}$ buffer system, when the stock solution did not contain the polyammonium, the relative activity of BOD was lowered to $0.17 \pm 0.06$ for 2 days, which is as much as the reference value of $0.19 \pm 0.02$ obtained for the MOPSH${ }^{ \pm}-\mathrm{MOPS}^{-}$system. The values for the QM3, QM4, and QM5 salts are somewhat lower than those in the
Table 2 Relative activities of $0.2 \mathrm{~g} / \mathrm{l}$ BOD stored in $0.5 \mathrm{~g} / \mathrm{l}$ QM3, QM4, and QM5 salts, $0.1 \mathrm{M} \mathrm{H}_{2} \mathrm{PO}_{4}{ }^{-}-\mathrm{HPO}_{4}{ }^{2-}$ and BisTrisH $^{+}-$BisTris $^{0}$ system $\left(\mathrm{pH} \mathrm{7.0)}\right.$ ) at $30^{\circ} \mathrm{C}$ for 2 days

\begin{tabular}{lcccc}
\hline & None & QM3 & QM4 & QM5 \\
\hline $\mathrm{H}_{2} \mathrm{PO}_{4}{ }^{-}-\mathrm{HPO}_{4}{ }^{2-}$ & $0.17 \pm 0.06$ & $0.27 \pm 0.04$ & $0.27 \pm 0.05$ & $0.28 \pm 0.05$ \\
BisTrisH $^{+}-$BisTris $^{0}$ & $0.51 \pm 0.08$ & $0.64 \pm 0.11$ & $0.58 \pm 0.11$ & $0.89 \pm 0.15$ \\
\hline
\end{tabular}

MOPSH ${ }^{ \pm}-\mathrm{MOPS}^{-}$system, indicating that the divalent $\mathrm{HPO}_{4}{ }^{2-}$ anion affects also on the formation equilibrium of the polyammonium with anionic BOD macromolecule.

In BisTris- $\mathrm{HCl}$, that is, the BisTrisH ${ }^{+}-\mathrm{BisTris}^{0}$ buffer system, when the stock solution did not contain the polyammonium, the relative activity of BOD was determined to be $0.51 \pm 0.08$, which is much higher than the reference value for the $\mathrm{MOPSH}^{ \pm}-$ MOPS $^{-}$system. The BisTrisH ${ }^{+}$cation has five hydroxyl groups. Therefore, the monomeric cation coexisting at a high concentration may act like a protective colloid in a similar manner to the polyammonium cations. The values for the QM3, QM4, and QM5 salts are somewhat higher than the reference value of $0.51 \pm 0.08$ in the $\mathrm{BisTrisH}^{+}$-BisTris ${ }^{0}$ system, indicating that the polyammonium cations also stabilize BOD in the buffer system.

The membrane-covered electrode with the internal solution phase containing only BOD was prepared. Solid curve a) in Fig. 2 shows the $\mathrm{CV}$ of the air-saturated test solution recorded immediately after immersion of the electrode. The S-shaped current-voltage curve with a steady state limiting current, which can be assigned to a $\left[\mathrm{Fe}(\mathrm{CN})_{6}\right]^{4-13-}$-mediated bioelectrocatalytic current, is exhibited. As shown by solid curves b) and c), the limiting current decreased with time. The limiting current of the air-saturated test solution with the electrode 2 days after the immersion was almost equal to that for the deaerated test solution (dashed curve in Fig. 2), indicating that BOD was completely inactivated within only 2 days.

The membrane-covered electrode with the internal solution phase containing BOD and QM4 salt was immersed continually in the $10 \mu \mathrm{M} \mathrm{K}_{4}\left[\mathrm{Fe}(\mathrm{CN})_{6}\right], 0.1 \mathrm{M} \mathrm{NaCl}, 0.05 \mathrm{M}$ BisTris-HCl test solution, and the $\mathrm{CV}$ was recorded at different times after immersion. The test solution was stirred continually. The experiment was carried out at ambient temperature. Immediately after immersion of the electrode, the limiting current mentioned below increased with time, indicating that $\left[\mathrm{Fe}(\mathrm{CN})_{6}\right]^{4-}$ transferred through the membrane from the test solution into the internal solution phase, and associated to the QM4 cation to form the QM4-[Fe( $\left.(\mathrm{CN})_{6}\right]^{4-13-}$ complex species. The limiting current kept increasing for more than several hours after immersion of the electrode into the test solution, suggesting that the formation equilibrium of the polyammonium cations and the $\left[\mathrm{Fe}(\mathrm{CN})_{6}\right]^{4-13-}$ anion is not reached rapidly.

Solid curve a) in Fig. 3 shows the CV of the air-saturated test solution recorded 1 day after immersion. The scan rate was $0.002 \mathrm{~V} \mathrm{~s}^{-1}$. An S-shaped current-voltage curve with a steady state limiting current is exhibited. The half-wave potential was 


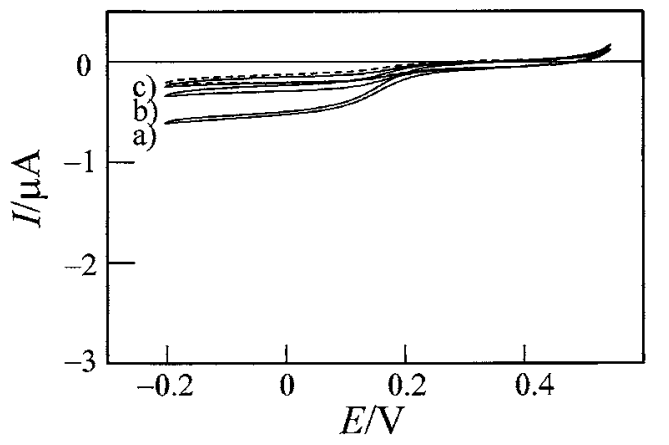

Fig. 2 Cyclic voltammograms of the air-saturated $10 \mu \mathrm{M}$ $\mathrm{K}_{4}\left[\mathrm{Fe}(\mathrm{CN})_{6}\right], 0.1 \mathrm{M} \mathrm{NaCl}$, and $0.05 \mathrm{M}$ BisTris- $\mathrm{HCl}$ solution ( $\left.\mathrm{pH} 7.0\right)$ a) 0 , b) 1 , and c) 2 days after immersion of the membrane-covered electrode with the internal solution phase containing only BOD (solid line), and of the deaerated test solution (dashed line). Scan rate, $0.002 \mathrm{~V} \mathrm{~s}^{-1}$

several tens of millivolts more positive potentials than that obtained with the membrane-covered electrode, which did not contain the polyammonium (see Fig. 2, above). As shown by the dashed curve in Fig. 3, when the test solution was deaerated by bubbling argon gas, the voltammetric current decreased remarkably. The results indicated that the limiting current can be assigned to a QM4-[Fe( $\left.\mathrm{CN})_{6}\right]^{4-13-}$-mediated bioelectrocatalytic current for the reduction of $\mathrm{O}_{2}$ by BOD. As shown by solid curves b) - d) in Fig. 3, the limiting current decreased with time, indicating that the inactivation of BOD was proceeding in the internal solution phase. However, the limiting current was observed remarkably, even if 8 days after immersion of the electrode. Although the comparison with the experimental results in the stock solution is not simple, it is interesting that the stabilizing effect of the polyammonium cation on BOD was also demonstrated in the electrode system.

Thus it can be concluded that the polyammonium cations comprising quaternary ammonium and the hydrophilic group, are useful for the enzyme-immobilized electrode, not only as a component of the electron-mediator, but also as an enzyme stabilizer. The study is now being extended to other redox enzyme systems.

\section{Acknowledgements}

The authors are grateful to Ms. Mika Tsuchida for assistance in the experiment. This work was supported by the Grants-in-Aid for Scientific Research from Fukui Prefectural University (to H. K.) and by the Special Coordination Funds for Promoting

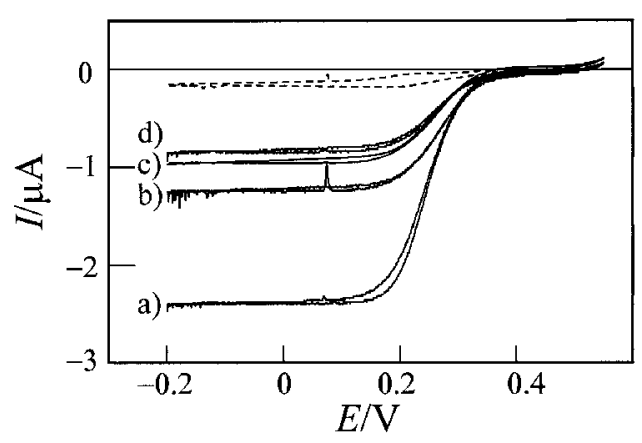

Fig. 3 Cyclic voltammograms of the air-saturated $10 \mu \mathrm{M}$ $\mathrm{K}_{4}\left[\mathrm{Fe}(\mathrm{CN})_{6}\right], 0.1 \mathrm{M} \mathrm{NaCl}$, and $0.05 \mathrm{M}$ BisTris- $\mathrm{HCl}$ solution (pH 7.0) a) 1 , b) 2 , c) 4 , and d) 8 days after immersion of the membranecovered electrode with the internal solution phase containing QM4 and BOD (solid line), and of the deaerated test solution (dashed line). Scan rate, $0.002 \mathrm{~V} \mathrm{~s}^{-1}$.

Science and Technology of the Ministry of Education, Culture, Sports, Science, and Technology, the Japanese Government (to H. T.).

\section{References}

1. H. Katano, H. Tatsumi, T. Hibi, T. Ikeda, and T. Tsukatani, to be submitted.

2. K. Ueno and K. Kina, J. Chem., 1985, 62, 627.

3. "Kobunshi Bussei no Kiso (in Japanese)", ed. the Society Polymer Science, Japan, 1993, Kyoritsu Shuppan, Tokyo, 73.

4. R. Zana, in "Polymer-Surfactant Systems", ed. J. C. T. Kwak, 1998, Marcel Dekker, New York, 410.

5. "Suiyouseikobunshi no Kinou to Ouyou (in Japanese)", ed. T. Horiuchi, 2005, CMC, Tokyo, 268.

6. K. Kano and T. Ikeda, Bunseki (in Japanese), 2003, 576.

7. "Biodenkikagaku no Jissai-Biosensa.Biodenchi no Jitsuyou Tenkai (Practical Bioelectrochemistry-Recent Developments in Biosensors \& Biofuel Cells, in Japanese)", ed. T. Ikeda, 2007, CMC Publishing, Tokyo.

8. S. C. Barton, J. Gallaway, and P. Atanasov, Chem. Rev., 2004, 104, 4867.

9. T. Ikeda, H. Tatsumi, H. Katano, M. Wanibuchi, and T. Hibi, Anal. Sci., 2008, 24, 237.

10. H. Katano, I. Kameoka, Y. Murayama, H. Tatsumi, T. Tsukatani, and M. Makino, Anal. Sci., 2004, 20, 1581.

11. T. Ikeda and M. Senda, Agric. Biol. Chem., 1978, 42, 679. 